\title{
Awareness and Knowledge of Adult Saudi Patients with Visual Impairment about Cataract
}

\author{
ABDULRAHMAN ALAMRI, M.D. ${ }^{\mathbf{1}}$; ABDULHAMID ALGHAMDI, M.D. ${ }^{\mathbf{2}}$; RANA S ALOJAIR, M.B.B.S. ${ }^{\mathbf{3}}$; \\ BASHAIR M ESSA, M.B.B.S. ${ }^{\mathbf{3}}$; ASHWAQ M ALSHAHRANI, M.B.B.S. ${ }^{\mathbf{3}}$ and OSSAMA A. MOSTAFA, D.R.Ph. ${ }^{4}$ \\ The Departments of Ophthalmology, College of Medicine, King Khalid ${ }^{1}$, Taif ${ }^{2}$, Abha, Saudi Arabia ${ }^{3}$ Universities and $^{2}$ \\ Family \& Community Medicine, College of Medicine, King Khalid University ${ }^{4}$
}

\begin{abstract}
Background: Cataract is the leading cause for visual impairment among people of developing and underdeveloped countries.

Aim of Study: This study aimed to identify the common patterns of eye diseases among patients with visual impairment and to assess their awareness and knowledge regarding cataract.

Patients and Methods: A cross-sectional study was conducted in Abha City, Saudi Arabia from October 2017 till December 2017. A total of 300 Saudi adult patients were included. A study questionnaire was used for data collection that evaluates participants' knowledge and awareness about cataract.

Results: Among participants, $77 \%$ heard about cataract and $66.3 \%$ knew that it is "clouding of normally clear lens" while $70 \%$ perceived cataract, as an "age-related disease". Hypertension $(48 \%)$, diabetes $(67.3 \%)$ and corticosteroids usage $(49.7 \%)$ were considered as the main precipitating factors for development of cataract. A vast majority (82\%) believed that cataract causes decreased visual acuity. Surgery as treatment of cataract was identified by only $61.3 \%$ of participants. Only $54 \%$ knew that cataract can lead to loss of vision.

Conclusions: There is lack of awareness and knowledge among Saudi adult eye patients in Abha City regarding cataract. Hence, health education of the public regarding cataract risk factors, prevention and treatment should be undertaken to encourage efforts for prevention and seeking early detection and to avoidance of complications of cataract.
\end{abstract}

Key Words: Cataract - Knowledge-Awareness - Risk factors - Prevention - Treatment.

\section{Introduction}

THE proper functioning of visual sensory organs is necessary for leading a good quality of life. Visual impairment negatively affects the quality of life by making the affected person dependent on others [1].

Correspondence to: Dr. Abdulrahman Alamri,

The Department of Ophthalmology, College of Medicine, King Khalid University
Cataract is the leading cause for visual impairment among people of developing and underdeveloped countries $[2,3]$. It is a multifactorial disease, wherein opacification of the eye lens occurs, causing increased light scattering. Its symptoms include blurred or cloudy vision, glare, seeing halos around light and being unable to see properly in low/dim light. Various factors associated with cataract development include increasing age, exposure to ultraviolet rays, genetic factors, trauma, smoking and use of corticosteroids [4-9] .

Development of cataract and the associated visual impairment is a gradual process. However, if left untreated, it can lead to complete blindness. In the southwestern region of Saudi Arabia, cataract was found to be responsible for visual impairment in $20.6 \%$ of cases and was responsible for more than half of cases of complete blindness [10].

Cataract treatment and its care are very costly, and constitutes a financial burden, especially among low socioeconomic class patients. Even though cataract is an age-related disease, identification of its risk factors led to the development of novel interventions, which can either delay or prevent its progression [11]. Timely arrangement of preventive and treatment strategies for cataract can reduce the economic and public health burden of this disease [12]. However, in developing countries, the lack of awareness about the disease is a major obstacle in decreasing visual impairment attributed to cataract [13].

Therefore, the present study aimed to identify the common patterns of eye diseases among patients with visual impairment and to assess their awareness and knowledge regarding cataract. 


\section{Subjects and Methods}

A cross-sectional study was conducted at a the Ophthalmology Clinic in Aseer Central Hospital, Abha City, Kingdom of Saudi Arabia during the period from October 2017 till December 2017. A total of 300 Saudi adult patients were included in the study. An informed consent was obtained from each participant.

A structured questionnaire was developed in a simple Arabic language by the researchers for data collection. It included patients' personal characteristic and questions related to awareness and basic knowledge (causes, risk factors, and treatment) regarding cataract. These questions were produced by a board of specialists to build up content validity.

All collected data were analyzed using the Statistical software of Social Sciences (SPSS, Chicago, IL, USA version 21). Data were represented using descriptive statistics such as frequency and percentages while continuous data were presented as mean \pm standard deviations. Chi-square test was used find the association between various variables and participants' awareness regarding cataract. $p$-values less than 0.05 were considered as statistically significant.

\section{Results}

The current study included 300 patients with a mean age of $35.3 \pm 14.5$ years (Range: $18-78$ years). One third of patients $(33 \%, n=99)$ aged $20-29$ years and about two thirds of them were females $(62 \%$, $\mathrm{n}=186$ ).

Amidst ophthalmic disorders, about half of patients $(47 \%, n=141)$ had errors of refraction e.g., myopia/hypermetropia, followed by cataract $(10.7 \%, n=32)$, glaucoma $(6 \%, n=18)$ and other eye diseases $(33.7 \%, \mathrm{n}=101)$, as shown in Fig. (1). Errors of refraction (myopia-hypermetropia) were the most prevalent among patients aged $<60$ years, while cataract and glaucoma were the most prevalent causes for impaired visual acuity among patients of age $>60$ years (Fig. 2). Causes for impaired visual acuity did not differ markedly according to patients' gender (Fig. 3).

Regarding awareness and knowledge about cataract, $77 \%(\mathrm{n}=231)$ of participants heard about it. Family $(24.7 \%)$, friends $(22.7 \%)$, magazines $(12.3 \%)$ and ophthalmologists $(11.3 \%)$ were the main sources of information about cataract. About two thirds of participants $(66.3 \%, \mathrm{n}=199) \mathrm{knew}$ that cataract is "clouding of normally clear lens". Cataract, was perceived as an "age-related disease" by $70 \%(n=210)$ of participants.

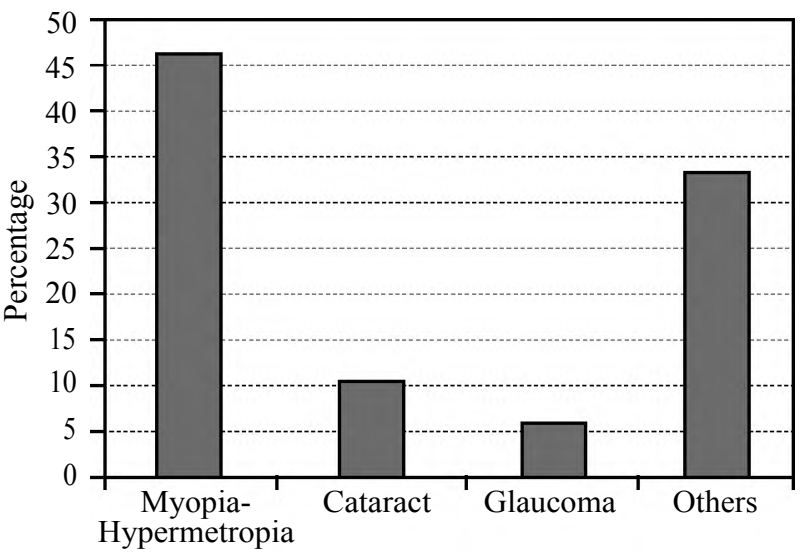

Fig. (1): Main causes for impaired visual acuity among patients attending the Ophthalmology Clinic in Abha City.

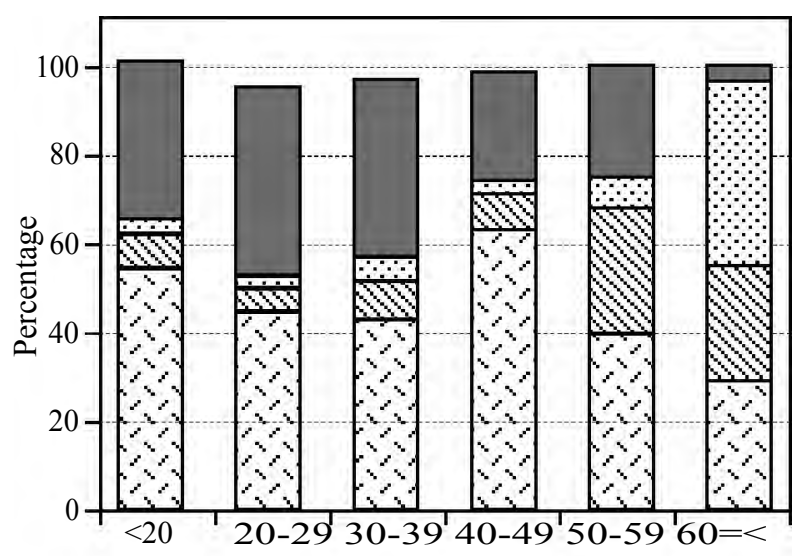

Age groups

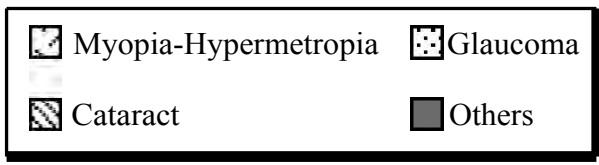

Fig. (2): Causes for impaired visual acuity among patients attending the Ophthalmology Clinic in Abha City according to their age groups.

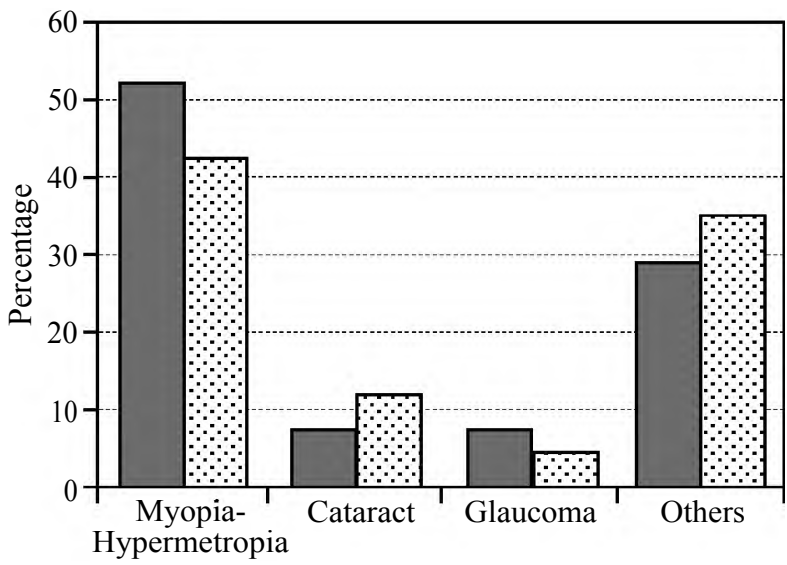

Male $\quad \because$ Female

Fig. (3): Causes for impaired visual acuity among patients attending the Ophthalmology Clinic in Abha City according to their gender. 
Male and female participants had almost the same perception about cataract (Table 1). Taking age of participants into consideration, most patients within all age groups believed that cataract is "opacification of the lens" and it is an "age-related disorder" (Table 2). Moreover, among the patients who already had cataract, $90 \%$ of them believed that cataract is "clouding of eye lens" although they did not know that it is an age-related disorder (Table 3).

Considering risk factors of cataract, $71.3 \%$ $(n=214)$ stated that cataract is an age-related disease. Hypertension was considered as a risk factor for cataract by $48 \%(n=144)$ of participants. A greater proportion $(67.3 \%, \mathrm{n}=202)$ were aware that diabetes mellitus (DM) is a risk factor for cataract. A minor fraction $(28.7 \%, \mathrm{n}=86)$ only considered smoking to be a risk factor for cataract. Approximately half of the study population $(49.7 \%, \mathrm{n}=149)$ believed that Corticosteroids constitute a risk factor for cataract. Lack of exercise was considered by $27.7 \%(n=83)$ as a risk factor. Males, significantly more than females, believed that smoking and lack of exercise are associated with development of cataract (Table 1). Smoking is the risk factor for cataract was believed mainly by elderly patients (Table 2). Patients with cataract, significantly more than others, believed that hypertension and diabetes mellitus are the risk factors for cataract (Table 3 ).

Regarding cataract symptoms and its treatment, most participants $(82 \%, \mathrm{n}=246)$ believed that cataract causes visual impairment. On the other hand, a significant proportion also believed that cataract causes redness and pain in eye $(36.7 \%, \mathrm{n}=110)$, halo is formed around the light they see (39\%, $\mathrm{n}=117)$, and causes headache and nausea $(39.7 \%$, $\mathrm{n}=119)$. About one third participants $(32.3 \%, \mathrm{n}=97)$ were unaware of any symptoms of cataract, $54.7 \%$ $(n=164)$ stated that cataract can lead to blindness, whereas $45.3 \%$ were unaware of it. Surgery for treatment of cataract was known to only $61.3 \%$ $(\mathrm{n}=184)$ participants. Almost one fourth of participants $(22.3 \%, \mathrm{n}=67)$ had no idea on treating cataract. Elderly people (aged $>60$ years) had misconceptions about cataract symptoms and less knowledge about its treatment (Table 2). Although cataract patients knew that cataract causes loss in vision, they also had misconception that cataract is associated with headache and nausea and causes redness and pain in the eyes. Patients with eye diseases also knew that cataract can be treated surgically and if untreated, it can lead to blindness (Table 3).

Table (1): Participants' awareness about cataract according to their gender.

\begin{tabular}{lllll}
\hline Awareness about cataract & $\begin{array}{c}\text { Total } \\
\text { No. }(\%)\end{array}$ & $\begin{array}{c}\text { Male } \\
\text { No. }(\%)\end{array}$ & $\begin{array}{c}\text { Female } \\
\text { No. }(\%)\end{array}$ & $p$-value \\
\hline What is cataract? & & & & \\
$\quad$ Disease that damage optic nerve & $58(19.3)$ & $17(14.9)$ & $41(22)$ & 0.288 \\
$\quad$ Clouding of normally clear eye & $199(66.3)$ & $81(71.1)$ & $118(63.4)$ & \\
Retina separates from the layer underneath & $43(14.3)$ & $16(14)$ & $27(14.5)$ & \\
Cataract can affect any age? & & & & \\
<10 years & $15(5.0)$ & $6(5.3)$ & $9(4.8)$ & \\
20-40 years & $75(25.0)$ & $29(25.4)$ & $46(24.7)$ & 0.974 \\
>-60 years & $210(70.0)$ & $79(70.4)$ & $131(69.3)$ & \\
Risk factors: & & & & \\
Aging & $214(71.3)$ & $84(73.7)$ & $130(69.9)$ & 0.513 \\
Hypertension & $144(48)$ & $56(47.3)$ & $88(49.1)$ & 0.812 \\
Diabetes mellitus & $202(67.3)$ & $83(72.8)$ & $119(64)$ & 0.129 \\
Smoking & $86(28.7)$ & $49(43.0)$ & $37(19.9)$ & $0.000^{*}$ \\
Lack of exercise & $83(27.7)$ & $42(36.8)$ & $41(22.0)$ & $0.008^{*}$ \\
Corticosteroids & $149(49.7)$ & $55(48.2)$ & $94(50.5)$ & 0.722 \\
Don't know & $88(29.3)$ & $26(22.8)$ & $62(33.3)$ & 0.067 \\
Symptoms of cataract: & & & & \\
Decrease in vision & $246(82)$ & $87(76.3)$ & $159(85.5)$ & 0.062 \\
Redness and pain in eyes & $110(36.7)$ & $37(32.5)$ & $73(39.2)$ & 0.267 \\
Halos around light & $117(39)$ & $50(43.9)$ & $67(36.0)$ & 0.182 \\
Headache and nausea & $119(39.7)$ & $48(42.1)$ & $71(38.2)$ & 0.544 \\
Don't know & $97(32.3)$ & $31(35.5)$ & $66(27.2)$ & 0.162 \\
Treatment of cataract: & & & & \\
Using eye drops & $44(14.7)$ & $17(14.9)$ & $27(14.5)$ & \\
Surgery & $184(61.3)$ & $69(60.5)$ & $115(61.8)$ & 0.785 \\
Wearing glasses & $5(1.7)$ & $3(2.6)$ & $2(1.1)$ & \\
Don't know & $67(22.3)$ & $25(21.9)$ & $42(22.6)$ & \\
If untreated can cataract lead to blindness? & & & & \\
Yes & $164(54.7)$ & $61(53.5)$ & $103(55.4)$ & 0.457 \\
& & & & \\
\hline
\end{tabular}


Table (2): Participants' awareness about cataract according to their age groups.

\begin{tabular}{|c|c|c|c|c|c|c|c|}
\hline Awareness about cataract & $\begin{array}{c}<20 y \\
\text { No. }(\%)\end{array}$ & $\begin{array}{l}20-29 y \\
\text { No. }(\%)\end{array}$ & $\begin{array}{l}30-39 y \\
\text { No. }(\%)\end{array}$ & $\begin{array}{l}40-49 y \\
\text { No. }(\%)\end{array}$ & $\begin{array}{l}50-59 y \\
\text { No. }(\%)\end{array}$ & $\begin{array}{c}\geq 60 y \\
\text { No. }(\%)\end{array}$ & $\begin{array}{c}p- \\
\text { value }\end{array}$ \\
\hline $\begin{array}{l}\text { What is cataract? } \\
\text { Disease that damages optic nerve } \\
\text { Clouding of normally clear eye } \\
\text { Retina separates from the layer under- } \\
\text { neath }\end{array}$ & $\begin{array}{l}7(22.6) \\
20(64.5) \\
4(12.9)\end{array}$ & $\begin{array}{l}23(23.2) \\
55(55.6) \\
21(21.2)\end{array}$ & $\begin{array}{l}8(12.9) \\
45(72.6) \\
9(14.5)\end{array}$ & $\begin{array}{l}5(10.2) \\
38(77.6) \\
6(12.2)\end{array}$ & $\begin{array}{l}7(20.0) \\
27(77.1) \\
1(2.9)\end{array}$ & $\begin{array}{l}8(33.3) \\
14(58.3) \\
2(8.3)\end{array}$ & 0.055 \\
\hline $\begin{array}{l}\text { Cataract can affect which age? } \\
\quad<10 \text { years } \\
20-40 \text { years } \\
\geq 60 \text { years }\end{array}$ & $\begin{array}{l}2(6.5) \\
16(51.6) \\
13(41.9)\end{array}$ & $\begin{array}{l}7(7.1) \\
25(25.3) \\
67(67.7)\end{array}$ & $\begin{array}{l}2(3.2) \\
16(25.8) \\
44(71.0)\end{array}$ & $\begin{array}{l}4(8.2) \\
11(22.4) \\
34(69.4)\end{array}$ & $\begin{array}{l}0(0.0) \\
3(8.60) \\
32(91.4)\end{array}$ & $\begin{array}{l}0(0.0) \\
4(16.7) \\
20(83.3)\end{array}$ & $0.005^{*}$ \\
\hline $\begin{array}{l}\text { Risk factors: } \\
\text { Aging } \\
\text { Hypertension } \\
\text { Diabetes mellitus } \\
\text { Smoking } \\
\text { Lack of exercise } \\
\text { Corticosteroids } \\
\text { Don't know }\end{array}$ & $\begin{array}{l}19(61.3) \\
10(32.3) \\
17(54.8) \\
6(19.4) \\
7(22.6) \\
13(41.9) \\
10(32.3)\end{array}$ & $\begin{array}{l}69(69.7) \\
42(42.4) \\
64(64.6) \\
27(27.3) \\
27(27.3) \\
47(47.5) \\
35(35.4)\end{array}$ & $\begin{array}{l}48(77.4) \\
29(46.8) \\
39(62.9) \\
18(29.0) \\
16(25.8) \\
36(58.1) \\
26(41.9)\end{array}$ & $\begin{array}{l}38(77.6) \\
27(55.1) \\
37(75.5) \\
13(26.5) \\
15(30.6) \\
24(49.0) \\
7(14.3)\end{array}$ & $\begin{array}{l}21(60.0) \\
19(54.3) \\
25(71.4) \\
8(22.9) \\
9(25.7) \\
20(57.1) \\
9(25.7)\end{array}$ & $\begin{array}{l}19(79.2) \\
17(70.8) \\
20(83.3) \\
14(58.3) \\
9(37.5) \\
9(37.5) \\
1(4.20)\end{array}$ & $\begin{array}{l}0.250 \\
0.053 \\
0.178 \\
0.029 * \\
0.855 \\
0.429 \\
0.002 *\end{array}$ \\
\hline $\begin{array}{l}\text { Symptoms of cataract: } \\
\text { Decrease in vision } \\
\text { Redness and pain in eyes } \\
\text { Halos around light } \\
\text { Headache and nausea } \\
\text { Don't know }\end{array}$ & $\begin{array}{l}22(71.0) \\
9(29.0) \\
7(22.6) \\
9(29) \\
11(35.5)\end{array}$ & $\begin{array}{l}77(77.8) \\
29(29.3) \\
41(41.4) \\
34(34.3) \\
40(40.4)\end{array}$ & $\begin{array}{l}52(83.9) \\
23(37.1) \\
28(45.2) \\
19(30.6) \\
27(43.5)\end{array}$ & $\begin{array}{l}42(85.7) \\
16(32.7) \\
13(26.5) \\
20(40.8) \\
9(18.4)\end{array}$ & $\begin{array}{l}31(88.6) \\
17(48.6) \\
12(34.3) \\
19(54.3) \\
8(22.9)\end{array}$ & $\begin{array}{l}22(91.7) \\
16(66.7) \\
16(66.7) \\
18(75.0) \\
2(8.30)\end{array}$ & $\begin{array}{l}0.228 \\
0.011^{*} \\
0.007 * \\
0.001 * \\
0.002 *\end{array}$ \\
\hline $\begin{array}{l}\text { Treatment of cataract: } \\
\text { Using eye drops } \\
\text { Surgery } \\
\text { Wearing glasses } \\
\text { Don't know }\end{array}$ & $\begin{array}{l}6(19.4) \\
14(45.2) \\
0(0.0) \\
11(35.5)\end{array}$ & $\begin{array}{l}17(17.2) \\
55(55.6) \\
2(2) \\
25(25.3)\end{array}$ & $\begin{array}{l}7(11.3) \\
42(67.7) \\
0(0.0) \\
13(21.0)\end{array}$ & $\begin{array}{l}2(4.10) \\
37(75.5) \\
1(2.0) \\
9(18.4)\end{array}$ & $\begin{array}{l}6(17.1) \\
24(68.6) \\
0(0.0) \\
5(14.3)\end{array}$ & $\begin{array}{l}6(25.0) \\
12(50.0) \\
2(8.3) \\
4(16.7)\end{array}$ & 0.052 \\
\hline $\begin{array}{l}\text { If untreated can cataract lead to } \\
\text { blindness? } \\
\quad \text { Yes }\end{array}$ & $17(54.8)$ & $54(54.5)$ & $33(53.2)$ & $25(51.0)$ & $24(68.6)$ & $11(45.8)$ & 0.396 \\
\hline
\end{tabular}

* Statistically significant.

Table (3): Awareness and knowledge about cataract among patients with eye diseases.

\begin{tabular}{|c|c|c|c|c|c|c|}
\hline Awareness about cataract & $\begin{array}{c}\text { Myopia- } \\
\text { Hypermetropia } \\
\text { No. }(\%)\end{array}$ & $\begin{array}{l}\text { Cataract } \\
\text { No. }(\%)\end{array}$ & $\begin{array}{l}\text { Glaucoma } \\
\text { No. }(\%)\end{array}$ & $\begin{array}{l}\text { Others } \\
\text { No. }(\%)\end{array}$ & $\begin{array}{l}\text { Don't know } \\
\text { No. }(\%)\end{array}$ & $\begin{array}{c}p- \\
\text { value }\end{array}$ \\
\hline \multicolumn{7}{|l|}{ What is cataract? } \\
\hline Disease that damages optic nerve & $25(17.7)$ & $3(9.4)$ & $5(27.8)$ & $24(23.8)$ & $1(12.5)$ & \\
\hline Clouding of normally clear eye & $98(69.5)$ & $29(90.6)$ & $11(61.1)$ & $55(54.5)$ & $6(75)$ & $0.021 *$ \\
\hline $\begin{array}{l}\text { Retina separates from the layer under- } \\
\text { neath }\end{array}$ & $18(12.8)$ & $0(0.0)$ & $2(11.1)$ & $22(21.8)$ & $1(12.5)$ & \\
\hline \multicolumn{7}{|l|}{ Cataract can affect which age? } \\
\hline$<10$ years & $12(8.5)$ & $1(3.1)$ & $0(0.0)$ & $2(2.0)$ & $0(0.0)$ & \\
\hline $20-40$ years & $27(19.1)$ & $11(34.4)$ & $4(22.2)$ & $32(31.7)$ & $1(12.5)$ & 0.101 \\
\hline$\geq 60$ years & $102(72.3)$ & $20(62.5)$ & $14(77.8)$ & $67(66.3)$ & $7(87.5)$ & \\
\hline \multicolumn{7}{|l|}{ Risk factors: } \\
\hline Aging & $102(72.3)$ & $22(68.8)$ & $16(88.9)$ & $68(67.3)$ & $6(75.0)$ & 0.443 \\
\hline Hypertension & $68(48.2)$ & $24(75.0)$ & $10(55.6)$ & $37(36.6)$ & $5(62.5)$ & $0.004 *$ \\
\hline Diabetes mellitus & $91(64.5)$ & $31(96.9)$ & $14(77.8)$ & $61(60.4)$ & $5(62.5)$ & $0.003 *$ \\
\hline Smoking & $43(30.5)$ & $5(15.6)$ & $7(38.9)$ & $26(25.7)$ & $5(62.5)$ & 0.069 \\
\hline Lack of exercise & $40(28.4)$ & $7(21.9)$ & $7(38.9)$ & $27(26.7)$ & $2(25)$ & 0.777 \\
\hline Corticosteroids & $67(47.5)$ & $14(43.8)$ & $12(66.7)$ & $51(50.5)$ & $5(62.5)$ & 0.502 \\
\hline Don't know & $34(24.1)$ & $3(9.4)$ & $1(5.6)$ & $49(48.5)$ & $1(12.5)$ & $0.000 *$ \\
\hline \multicolumn{7}{|l|}{ Symptoms of cataract: } \\
\hline Decrease in vision & $119(84.4)$ & $31(96.9)$ & $16(88.9)$ & $73(72.3)$ & $7(87.5)$ & $0.014 *$ \\
\hline Redness and pain in eyes & $36(25.5)$ & $25(78.1)$ & $12(66.7)$ & $35(34.7)$ & $2(25.0)$ & $0.000 *$ \\
\hline Halos around light & $52(36.9)$ & $12(37.5)$ & $11(61.1)$ & 39 (38.6) & $3(37.5)$ & 0.405 \\
\hline Headache and nausea & $52(36.9)$ & $22(68.8)$ & $12(66.7)$ & $27(26.7)$ & $6(75)$ & $0.000 *$ \\
\hline Don't know & $36(25.5)$ & $4(12.5)$ & $1(5.6)$ & $55(54.5)$ & $1(12.5)$ & $0.000^{*}$ \\
\hline \multicolumn{7}{|l|}{ Treatment of cataract: } \\
\hline Using eye drops & $16(11.3)$ & $11(34.4)$ & $4(22.2)$ & 12 (11.9) & $1(12.5)$ & \\
\hline Surgery & $96(68.1)$ & $18(56.3)$ & $8(44.4)$ & $55(54.5)$ & $7(87.5)$ & $0.006^{*}$ \\
\hline Wearing glasses & $1(0.7)$ & $1(3.1)$ & $1(5.6)$ & $2(2.0)$ & $0(0.0)$ & \\
\hline Don't know & $28(19.9)$ & $2(6.3)$ & $5(27.8)$ & $32(31.7)$ & $0(0.0)$ & \\
\hline \multicolumn{7}{|l|}{$\begin{array}{l}\text { If untreated can cataract lead to } \\
\text { blindness? }\end{array}$} \\
\hline Yes & $83(58.9)$ & $10(31.3)$ & $8(44.4)$ & $59(58.4)$ & $4(50.0)$ & $0.015^{*}$ \\
\hline
\end{tabular}

* Statistically significant. 


\section{Discussion}

In this cross-sectional study, cataract-related knowledge and awareness were assessed among patients with visual impairment in Abha City. It has been shown in the present study that about two-third population know that cataract is "lens opacity" and is an "age-related disease".

Several local studies reported less awareness regarding cataract among their study samples. According to the study of Alghamdi et al. [12], in Al-Baha City, Saudi Arabia, less than one third of the study general population realized that cataract is an "expansion in focal point darkness". However, their knowledge of consequences of cataract was not sufficient and nearly half of participants knew that cataract could cause blindness. Similarly, the study of Magliyah et al., [1] among adult population in Makkah City also observed their lack of awareness about cataract. They attributed this to the wide knowledge gaps in health education programs provided by health care providers.

The apparently better awareness among our study sample may be due to the fact that our participants were patients with impaired visual acuity, while participants in the other local studies were mainly from the general Saudi population. It is to be noted the only substantial general wellbeing instruction regarding cataract in Saudi Arabia was supported by the Saudi Ophthalmology Society, in collaboration with King Khalid Eye Specialist Hospital [14].

In accordance with findings of Alghamdi et al., [13], the present study showed that hypertension and diabetes mellitus were considered by participants as important risk factors for cataract. This could be explained by the high prevalence of diabetes reported among Saudi adult population $[15,16]$ and the continued efforts put forward by the Saudi Ministry of Health in promoting awareness about diabetes and its complications [17]

Similarly, a great proportion of participants in this study considered surgery to be the recommended treatment for cataract. This is similar to the results reported by Alghamdi et al., [13]. However, Magliyah et al., [1] found poor awareness among the general population in Makkah Region regarding the treatment of cataract, where almost two-thirds of the study subjects were unaware how cataract is dealt with when it impairs vision.

In this survey, although more than three-fourths of participants held the view that cataract leads to impaired vision, few of them, including patients having cataract, had the misconception that it is associated with symptoms like headache, nausea, and redness of eye. In addition, it was observed that knowledge among cataract patients about cataract perception, risk factors and treatment was not significantly different from that of other participants who did not have cataract.

Cataract is responsible for $52.6 \%$ of blindness and $20.6 \%$ of causes for visual impairment in the southwestern region of Saudi Arabia [10]. Nonetheless in this study, more than half of participants, and even those with cataract, were mostly unaware about the fact that if left untreated, cataract can lead to progressive loss of vision and blindness. This emphasizes the pressing need of planning and conducting health education programs to be designed based on the gaps of public's awareness identified in this study. Improved understanding of the disease and its risk factors is expected to help in minimizing the incidence of cataract and will allow for improved eye care and better outcomes.

\section{Conclusions:}

The population in Abha City lack the necessary basic information regarding cataract. Therefore, considerable endeavors ought to be taken to expand the information and awareness regarding cataract. Widespread health education programs in Saudi Arabia should take the necessary steps to build up the level of mindfulness and information about cataract. This progression would prompt better understanding of the significance of routine eye check-up for early discovery and treatment of such conditions, and would reduce incidence of visual impairment and the cost of eye health care.

\section{References}

1- MAGLIYAH M.S., NAGEEB M.R., ABDULMANNAN D.M., BADR H.M., HEMMEISH M.M., ALOTAIBI W.T. and AZHARI E.F.: Assessment of knowledge regarding cataract among Saudi adult population in Makkah city, Saudi Arabia. Int. J. Med. Sci. Public. Health, 4: 595599, 2015.

2- LEE C.M. and AFSHARI N.A.: The global state of cataract blindness. Curr. Opin. Ophthalmol., 28 (1): 98-103, 2017.

3- BOURNE R.R., FLAXMAN S.R., BRAITHWAITE T., CICINELLI M.V., DAS A., JONAS J.B., et al.: Magnitude, temporal trends, and projections of the global prevalence of blindness and distance and near vision impairment: A systematic review and meta-analysis. The Lancet Global Health, 5 (9): 888-897, 2017.

4- ASBELL P.A., DUALAN I., MINDEL J., et al.: Agerelated cataract. Lancet., 365: 599, 2005.

5- HILLER R., SPERDUTO R.D., PODGOR M.J., WILSON P.W. and FERRIS F.L.: Cigarette smoking and the risk of 
development of lens opacities. In: Archives of ophthalmology. ${ }^{3}$ Ed., Colton. T. Chicago., pp: 1113-1118, 1997.

6- KLEIN B.E., KLEIN R. and LEE K.E.: Diabetes, cardiovascular disease, selected cardiovascular disease risk factors and 5-year incidence of age-related cataract and progression of lens opacities. American Journal of Ophthalmology, 126 (6): 782-790, 1998.

7- BOCHOW T.W., WEST S.K., AZAR A., MUNOZ B., SOMMER A. and TAYLOR H.R.: Ultraviolet light exposure and risk of posterior subcapsular cataracts. Archives of Ophthalmology (Chicago), 107 (3): 369-372, 1989.

8- KLEIN B.E., KLEIN R., LEE K. and DANFORTH L.G.: Drug use and five-year incidence of age-related cataracts. Ophthalmology, 108 (9): 1670-1674, 2001.

9- SALEEM S., AZEEMI M.S. and ABDULLAH R.: Cataract disease; awareness and its treatment among patient presenting to opthalmology Outdoor Jinnah Hospital Lahore. Professional. Med. J., 24 (9): 1420-1424, 2017.

10- AL FARAN M.F., AL-RAJHI A.A., AL-OMAR O.M., AL-GHAMDI S.A. and JABAK M.: Prevalence and causes of visual impairment and blindness in the south western region of Saudi Arabia. Int .Ophthalmol., 17 (3): 161-5, 1993.

11- CHANG J.R., KOO E., AGRON E., HALLAK J., CLEMONS T., AZAR D., et al.: Risk factors associated with incident cataracts and cataract surgery in the age-related eye disease study (AREDS). Ophthalmology, 118 (11): 2113-2119m, 2011
12- MISRA V., VASHIST P., SINGH S.S., MALHOTRA S. GUPTA V., DWIVEDI S.N., et al.: Awareness and eye health-seeking practices for cataract among urban slum population of Delhi: The North India eye disease awareness study. Indian J. Ophthalmol., 65: 1483-8, 2017.

13- ALGHAMDI A.H.A., ALAMRI A.M.A., ALZAHRANI R.A.M., ALGHAMDI A.A.M., ALGHAMDI S.Y.S., DOKHAIKH F.A.A., et al.: Awareness about Causes and Risk Factors of Cataract among General Population of Al-Baha City The Egyptian Journal of Hospital Medicine 69 (6): 2703-2710, 2017.

14- Saudi Ophthalmological Society. Cataract. Available at: http://213.230.15.195/sosnew/section/search cfm?txtsearch $=\% \mathrm{C} 7 \% \mathrm{E} 1 \% \mathrm{E} 3 \% \mathrm{C} 7 \% \mathrm{C} 1 \% 20 \% \mathrm{C} 7 \% \mathrm{E} 1$ $\% \mathrm{C} 3 \% \mathrm{C} 8 \% \mathrm{ED} \% \mathrm{D} 6 \& \mathrm{sr}=1 /$ (last accessed on December 24, 2017).

15- HAJAR S., AL HAZMI A., WASLI M., MOUSA A. and RABIU M.: Prevalence and causes of blindness and diabetic retinopathy in Southern Saudi Arabia. Saudi Medical Journal, 36 (4): 449- 455, 2015.

16- ALZEIDAN R., RABIEE F., MANDIL A., HERSI A. and FAYED A.: Non-communicable disease risk factors among employees and their families of a Saudi University: An epidemiological study. PloS One, 11 (11): 165036-165045, 2016.

17- AL RASHED W.A. and BIN ABDULRAHMAN A.K.: Public awareness regarding common eye diseases among Saudi adults in Riyadh City: A quantitative study. Journal of Ophthalmology, Article ID 9080791, 5 pages, https: //doi.org/10.1155/2017/ 9080791, 2017.

\section{وعى ومعرفة السعوديين البالغين المصابين بضعف الإبصار حول المياه البيضاء اليضاءئ}

$$
\begin{aligned}
& \text { هدف البحث: تحديد الأنماط الثائعة لأمراض العينن بين المرضى الدين يعانهن من ضعف البصر وتقييم وعيهم ومعرفتهم بشأن } \\
& \text { الإصابة بالمياه البيضاء. }
\end{aligned}
$$

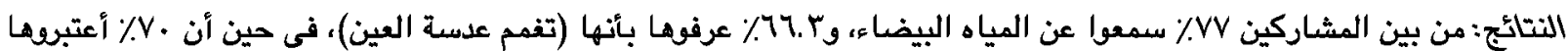

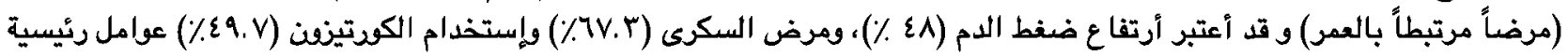

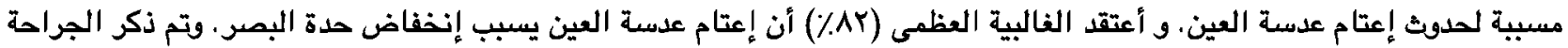

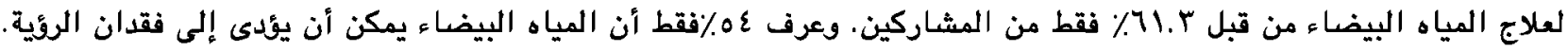

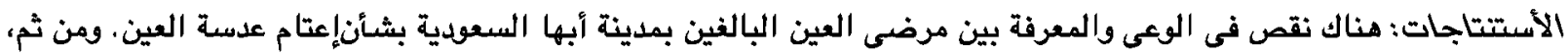

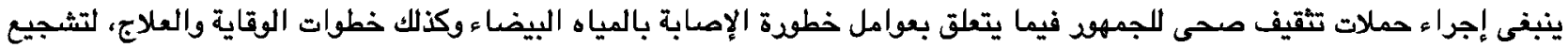

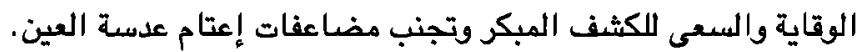

